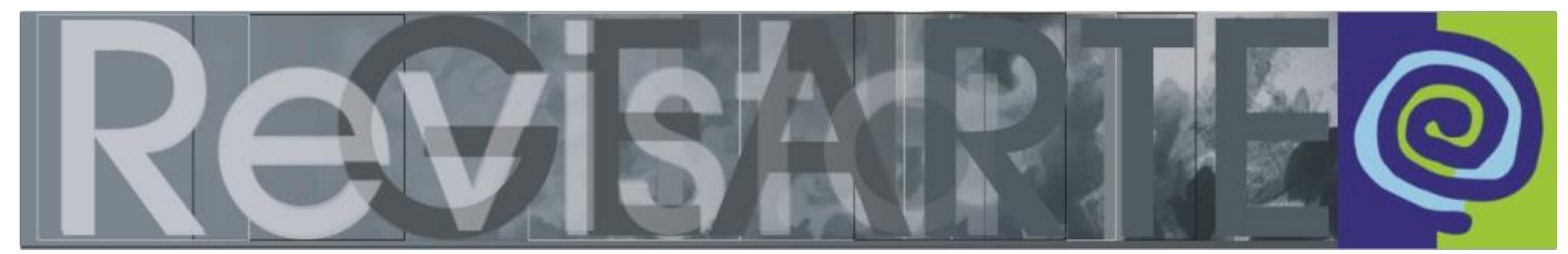

ISSN 2357-9854 | e-ISSN 2596-3198 (online)

\title{
CinEducar e Partejar Potiguara: o ensino do cinema para mulheres indígenas como ferramenta de (r)existência
}

\author{
Micaelle Lages Lucena \\ (Universidade Federal da Paraíba — UFPB, João Pessoa/PB, Brasil) \\ Isabella Chianca Bessa Ribeiro do Valle \\ (Universidade Federal da Paraíba — UFPB, João Pessoa/PB, Brasil)
}

\begin{abstract}
RESUMO - CinEducar e Partejar Potiguara: o ensino do cinema para mulheres indígenas como ferramenta de (re)existência - Este artigo visa a analisar algumas experiências vividas em campo no projeto de extensão universitária Partejar Potiguara, que propôs aulas de cinema para mulheres indígenas na região da Baía da Traição (PB) em 2019. O objetivo é analisar os atravessamentos e afetos gerados na busca por uma metodologia engajada e transgressora dentro de um contexto de lutas sociais e resistência cultural. Desde a seleção bibliográfica da pesquisa e as dificuldades encontradas nas aulas à execução do produto final (um documentário sobre parto, maternidade, vida e identidade), o propósito é compreender o ensino das artes visuais e a produção cinematográfica como ferramenta política de valorização da identidade.
\end{abstract}

\section{PALAVRAS-CHAVE}

Cinema e educação. Partejar Potiguara. Mulheres indígenas. Povo Potiguara da Paraíba. Documentário audiovisual indígena.

ABSTRACT - CinEducar e Partejar Potiguara: teaching filmmaking to indigenous women as a tool of (re)existence - This paper aims to analyze some field experiences in the Partejar Potiguara project, which proposed teaching filmmaking to indigenous women in the region of Baía da Traição (PB) in 2019. The goal is to analyze the crossings and affections created in the search for an engaged and transgressive methodology within a context of social struggles and cultural resistance. Since bibliographical selection and the difficulties found in class until the final product (a documentary about childbirth, maternity, life and identity), the purpose is to comprehend the teaching of visual arts and the film production as politic tool of identity affirmation and valuation.

\section{KEYWORDS}

Cinema and education. Partejar Potiguara. Indigenous women. Potiguara People of Paraíba. Indigenous audiovisual documentary.

RESUMEN - CinEducar y Partejar Potiguara: la enseñanza del cine a las mujeres indígenas como herramienta de (re) existência - Este artículo tiene como objetivo analizar algunas experiencias vividas en el campo en el proyecto de extensión universitaria Partejar Potiguara, que propuso clases de cine para mujeres indígenas en la región de Baía da Traição (PB) en 2019. El objetivo es analizar los cruces y afectos generados en la búsqueda de un metodología comprometida y transgresora dentro de un contexto de luchas sociales y resistencia cultural. Desde la selección bibliográfica de la investigación y las dificultades encontradas en clase hasta la ejecución del producto final (un documental sobre el parto, la maternidad, la vida y la identidad), el propósito es entender la enseñanza de las artes visuales y la producción cinematográfica como una herramienta política para valorar la identidad.

PALABRAS CLAVE

Cine y educación. Partejar Potiguara. Mujeres indígenas Pueblo Potiguara de Paraíba. Documental audiovisual indígena. 


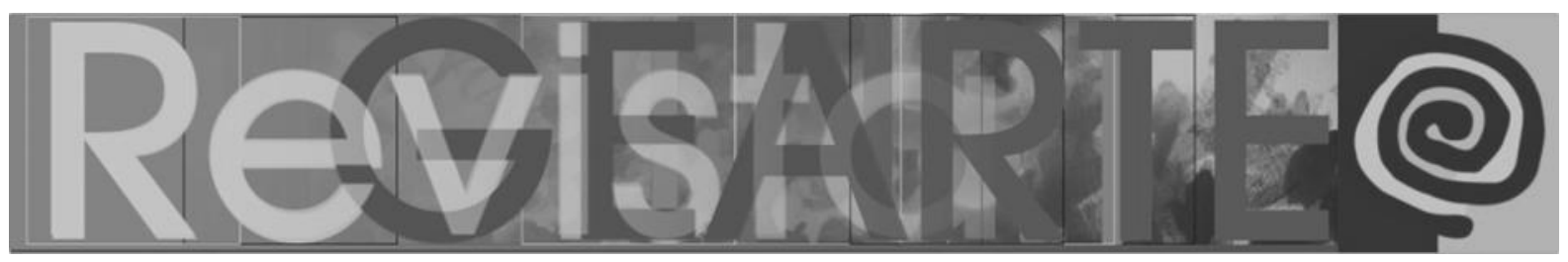

\section{Introdução}

Como assimilar a complexidade cultural e a diversidade da sociedade em que estamos inseridas e inseridos se, diariamente, as histórias que nos são contadas (e por quem são contadas) não correspondem a essa realidade? Em livros, revistas, novelas e também nas escolas, a ocupação de espaço das narrativas precisa ser expandida. Nascemos e crescemos habituadas e habituados a ver o mundo sob uma perspectiva colonizada e colonizadora, branca e eurocentrada, na qual qualquer sinal de alteridade cultural, epistêmica e existencial precisa ser tratado para se encaixar na "civilização". Muitos livros escolares de história inclusive apontam os processos de invasão territorial, mais conhecida por colonização, como atuações saudáveis de cidadãos empáticos buscando resgatar outros seres que viviam na completa ignorância. Por muito tempo, essa apropriação foi sinônima de desenvolvimento, de descobrimento, e "os chamados povos primitivos ${ }^{1}$ seriam os remanescentes de etapas iniciais desse desenvolvimento, e as sociedades europeias, o ponto mais elevado do processo de evolução das sociedades humanas" (BARBOSA, 2006, p. 7). Hoje entende-se que esse foi um longo, e arquitetado, projeto de genocídio, exploração, silenciamento e invisibilização de vários povos e suas culturas, principalmente as hoje ditas negras e indígenas, em prol de um projeto econômico que ainda ganha formas contemporâneas, que são o foco dos estudos neocoloniais (NKRUMAH, 1973), pós-coloniais (ASHCROFT, 1989; KILOMBA, 2008) e decoloniais (QUIJANO, 1988; ESCOBAR,1994).

Os povos indígenas por muito tempo vêm sendo representados em situações exóticas, para gerar uma oposição com a vivência das pessoas do mundo civilizado. "Tanto a antropologia como a fotografia e o cinema, em seus diferentes processos de construção do conhecimento, elaboram métodos e formas de representar, de dar corpo a uma imaginação existente sobre a alteridade."

1 Maneira pejorativa que os colonizadores utilizavam para se referir aos povos explorados, expulsos, assassinados e escravizados pela colonização europeia. 


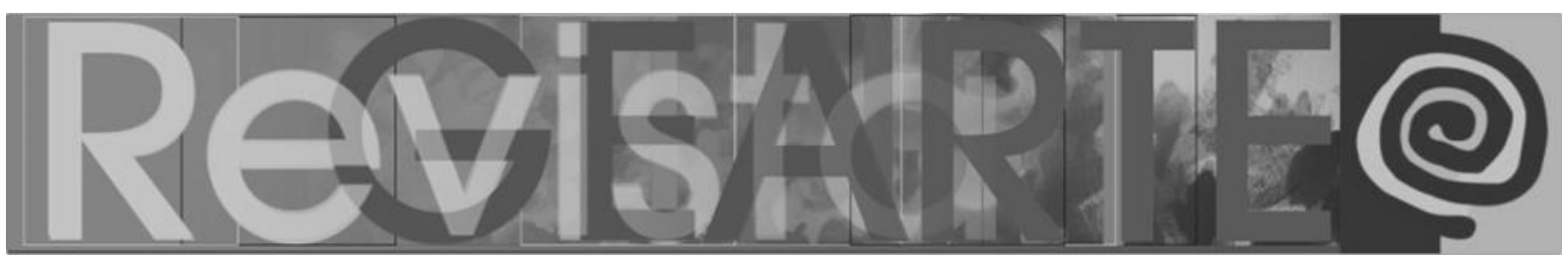

(BARBOSA, 2006, p. 8). Esse modo de retratar as pessoas estudadas diz mais sobre a visão dos que pesquisam e os estereótipos que carregam do que sobre a vida real daquela comunidade de que falam. As narrativas, verbais e imagéticas, carregam a visão daquele que as produz e escolhe, de forma tendenciosa, como quer contar aquela história.

O distanciamento, entre quem pesquisa e quem é pesquisada(o), quem fotografa e quem é fotografada(o), quem documenta e quem é documentada(o), vem sendo, sob uma epistemologia também eurocentrada, considerado como sinônimo de imparcialidade e "configura-se, desde esse período seminal, como um desafio tanto para a antropologia como para o cinema" (BARBOSA, 2006, p. 9) e também para a educação e a ciência como um todo. Assim como é difícil entender qual distância é preciso assumir nessa relação, para que a narrativa e seu próprio processo sejam validados, também é importante compreender que essa própria lógica e preocupação parte do estabelecimento de um outro, que, a princípio não parece apto a produzir narrativas sobre si mesmo. Estamos em uma imersão de atravessamentos de olhares e de parcialidades. Assim, a realidade precisa ser apresentada e representada em sua complexidade de olhares, principalmente por quem a História vem constantemente reservando a omissão.

Quebrar o ciclo da homogeneidade narrativa e educativa é descolonizar o olhar sobre a diversidade de existências. Assumir a alteridade como potência, e não como uma necessidade de assimilação e padronização. Fomentar a ocupação de espaços, as diversidades dos locais de fala e o fortalecimento de identidade, de representação e representatividade. Fundamentado na reflexão de bell hooks ${ }^{2}$ (2013), que propõe tudo isso que acaba de ser mencionado, o CinEducar ${ }^{3}$ é sobre enxergar o cinema como ferramenta de educação para fortalecimento e

2 A letra minúscula, que desafia convenções linguísticas e acadêmicas, pretende dar enfoque ao conteúdo da sua escrita e não à sua pessoa.

3 Um dos projetos analisados neste artigo do qual falaremos mais profundamente adiante.

LUCENA, Micaelle Lages; VALLE, Isabella Chianca Bessa Ribeiro do. CinEducar e Partejar Potiguara: 374 o ensino do cinema para mulheres indígenas como ferramenta de (r)existência. Revista GEARTE, Porto Alegre, v. 7, n. 2, p. 372-400, maio/ago. 2020.

Disponível em: http://seer.ufrgs.br/gearte 


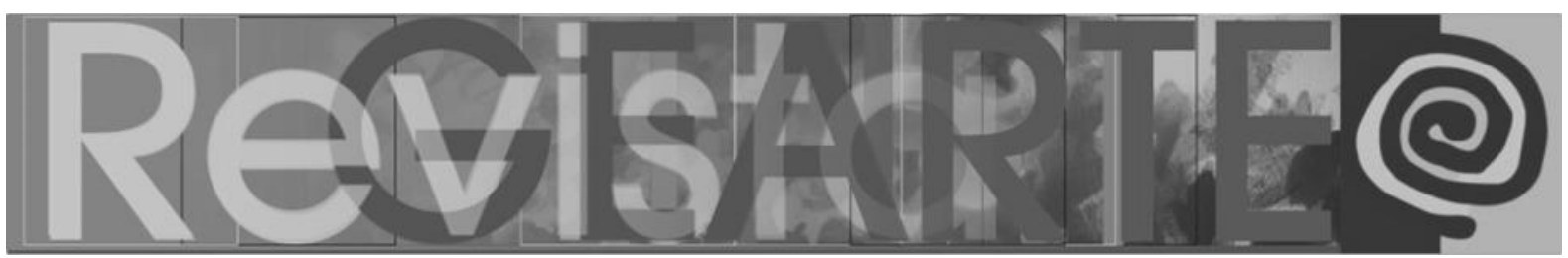

resistência, como potencialidade transgressora de que os povos historicamente silenciados possam se (re)conhecer e falar de si a partir do seu ponto de vista.

O desafio que permeou todo o projeto foi: como promover uma educação popular engajada e empoderadora? Como fazer a produção audiovisual quebrar as barreiras dos espaços legitimados, ultrapassando os muros de grandes centros urbanos e dos campi de universidades, para chegar às mãos de quem tem poder de gerar conteúdos com mais representatividade? Como estabelecer conexão dentro dessas salas de aula, gerar paixão e despertar interesse pelo conteúdo? Como alunas de graduação poderiam desenvolver metodologias de ensino do cinema que visam a amplificar outras vozes, discursos e resistências?

\section{O Partejar Potiguara e Cineducar: as aproximações do cinema e a educação}

O Partejar Potiguara é um macroprojeto de extensão da Universidade Federal da Paraíba iniciado no ano de 2019. É composto por professoras coordenadoras e estudantes de dois campi diferentes e de diversos cursos que se encaixam em três grandes áreas de conhecimento: Saúde, Antropologia e Comunicação. Feito majoritariamente por mulheres, buscou entrar em contato com as tradições das comunidades indígenas para uma troca de saberes e vivências sobre as práticas em torno do parto natural, através de uma parceria com mulheres Potiguara da Paraíba, cujo território está localizado no litoral norte do estado. É um projeto que visa à articulação de diversas ciências a fim de que cada uma possa fortalecer a atuação coletiva em campo e a pesquisa realizada, gerando debates enriquecidos por diversas epistemes e epistemologias.

A vertente da Comunicação, com alunas dos cursos de graduação em Cinema e Audiovisual, Radialismo e Jornalismo, entrou no projeto buscando promover a aproximação à linguagem audiovisual como ferramenta de criação e difusão de discursos e de saberes por parte da comunidade. Inspiradas por 


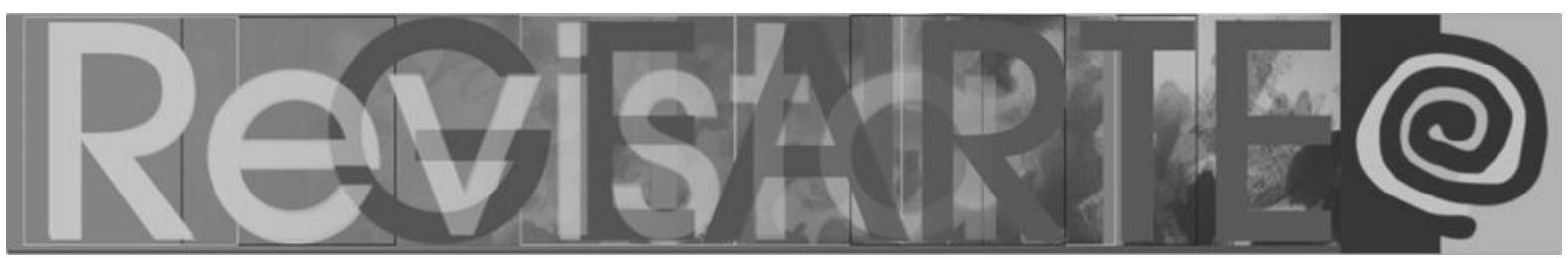

projetos como o Vídeo nas Aldeias ${ }^{4}$, uma Organização Não Governamental (ONG) de alcance nacional que busca levar a produção audiovisual para aldeias indígenas no intuito de promover uma realização autoral, no Partejar Potiguara, planejou-se a ideia inicial de ministrar aulas básicas de cinema e produção de filmes com objetivo de finalizar o ano com a realização de um documentário sobre os temas que permeavam os debates e a atuação do projeto de extensão.

Assim como essa ONG que, através de oficinas, capacita populações indígenas para produzir roteiros, dirigir e editar seus próprios filmes, o Partejar Potiguara surgiu, em sua vertente audiovisual, na intenção de incentivar a autonomia das jovens mulheres Potiguara que participassem das aulas, para que, através do cinema, falassem sobre temas com que convivem e são familiarizadas, produzindo assim seus próprios olhares e registros sobre sua comunidade. Sendo uma extensão que estuda, pesquisa e debate sobre assuntos que giram em torno da temática do parto, as mulheres foram o público-alvo que se instrumentalizaria com a arma política do fazer fílmico, na intenção de assumirem novos espaços de trabalho e de discurso.

A meta foi fomentar formação, produção e difusão audiovisual com mulheres indígenas através de visão e método que funcionassem como prática de autonomia e liberdade, fundamentadas em uma visão freireana (FREIRE, 1996). Em encontros quinzenais, o projeto Partejar Potiguara desenvolveu os meios de trocar conhecimentos com as alunas e, para além de transferir nomenclaturas técnicas, promoveu-se uma alfabetização cinematográfica: um extenso diálogo sobre a importância de ler, entender e produzir imagens. Tal processo se torna ainda mais importante na produção de autoimagem, por encontrar na elaboração do próprio

4 Criado em 1986, a partir de um experimento realizado por Vicent Carelli, foi precursor na área de produção audiovisual no Brasil. Atualmente se constitui como uma ONG independente com apoio do Governo Federal do Brasil, UNESCO, Embaixada da Noruega e Petrobras. Tem acervo com mais de 70 filmes, a maioria deles premiados nacional e internacionalmente. Mais informações podem ser encontradas no site oficial do projeto: http://www.videonasaldeias.org.br/2009/ 


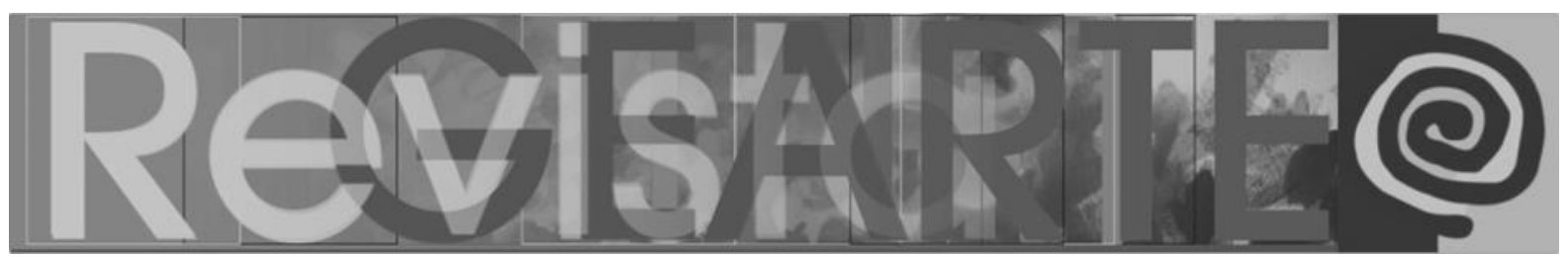

discurso potência de libertação. Assim como hooks (2013) fala sobre a política da vida cotidiana das pessoas negras no sul segregacionista dos Estados Unidos, onde negros que não eram alfabetizados frequentemente sofriam racismo e exclusão por isso e viviam em relação de maior dependência (hooks, 2013, p. 72), é possível traçar esse paralelo com a produção de imagens na atualidade: saber se autorrepresentar sem precisar de mediações gera empoderamento e autonomia.

O projeto articula uma base bibliográfica sobre cinema e educação que o apoia em sua prática extensionista. A partir dessa demanda, nasceu um projeto de pesquisa incentivado por um déficit na grade de disciplinas dos cursos de Comunicação da própria instituição: os estudantes são incentivados e ensinados a produzir e divulgar suas próprias produções, mas não encontram espaço para debates e aulas sobre como passar esse conteúdo adiante. Os cursos são construídos como bacharelados e não possuem nenhuma interseção de uma compreensão de prática através de possibilidades de licenciatura.

As universidades brasileiras têm como estrutura fundamental um tripé de atuação - ensino, pesquisa e extensão. "As funções seriam formar ou ensinar, investigar ou pesquisar e servir ou exercer a atividade de extensão" (OSPINA, 1990, p. 138 apud SLEUTJES, 1999, p. 101). São pilares dialéticos pelos quais o conhecimento se espalha e assume diferentes formas de aplicação: a transmissão de saberes em sala de aula, a pesquisa e a objetivação desse conhecimento através da extensão, em que a universidade se expande para fora dos seus muros buscando aplicar e democratizar os saberes. A pesquisa, sendo "o aprofundamento do conhecimento já existente, nascido da busca por soluções, da busca pelo novo, do gosto pela investigação, pela descoberta" (SLEUTJES, 1999, p. 106), foi o caminho ideal encontrado pelo projeto para enxergar os alunos dos cursos como potenciais educadores e as possibilidades para chegar até lá. 


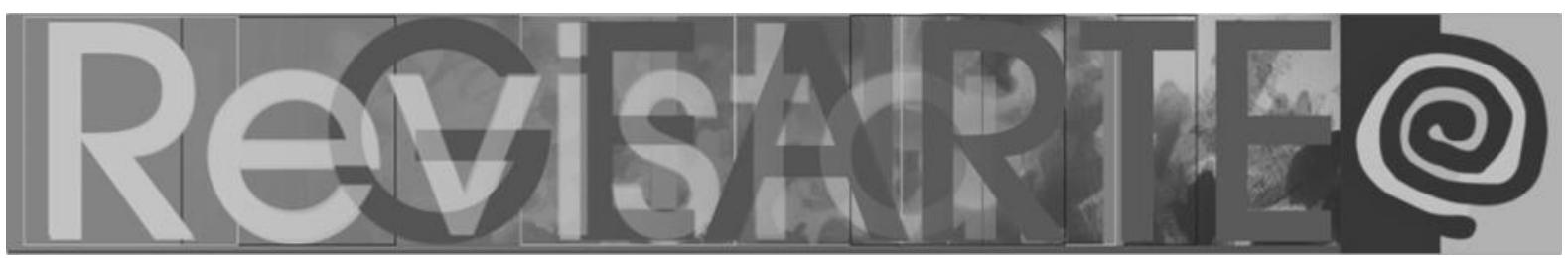

O projeto de pesquisa CinEducar foi planejado, então, para pensar também como minimizar a monopolização da produção de filmes, que acontece majoritariamente em centros urbanos e é dominada por uma classe, raça e gênero específicos. Outro objetivo é desmistificar a ideia de que são necessários muitos equipamentos para produzir um vídeo e contar histórias e, junto com outros projetos que atuam pulverizando o ensino do audiovisual para as minorias sociais, produzir conteúdo teórico sobre metodologias de ensino do audiovisual, com engajamento social e político, buscando a democratização desse espaço, da linguagem e de suas ferramentas de poder narrativo.

\section{Cinema e artes visuais}

Andrei Tarkovski, cineasta russo de grande importância no pós-guerra, discorre em um de seus livros sobre o objetivo fundamental da arte. "A arte é uma metalinguagem com a ajuda da qual os homens tentam comunicar-se entre si, partilhar informações sobre si próprios e assimilar a experiência dos outros" (TARKOVSKI, 1998, p. 43). Ele defendia que a arte tem o papel de fazer o artista conhecer a si mesmo e sua relação com o mundo em que vive, o significado de sua existência. Para ele, a grande função da arte é a comunicação, o espírito de comunhão. "E assim, a arte, como a ciência, é um meio de assimilação do mundo". (TARKOVSKI, 1998, p. 39).

O cinema é recente. Derivado da arte de fotografar, evoluiu no tempo cercado de diversas teorias sobre sua legitimidade como arte: diversos teóricos se debruçavam sobre questões como a especificidade do meio, o conceito de belo nas obras, a ocultação da técnica, entre outros. Jacques Aumont, em seu livro $O$ olho interminável (2004), corrobora com a ideia de teóricos como Eisenstein ao defender que assim como a pintura é a arte do tempo, devemos considerar o cinema como a arte do espaço, promovendo assim um estudo dialético entre as artes. 


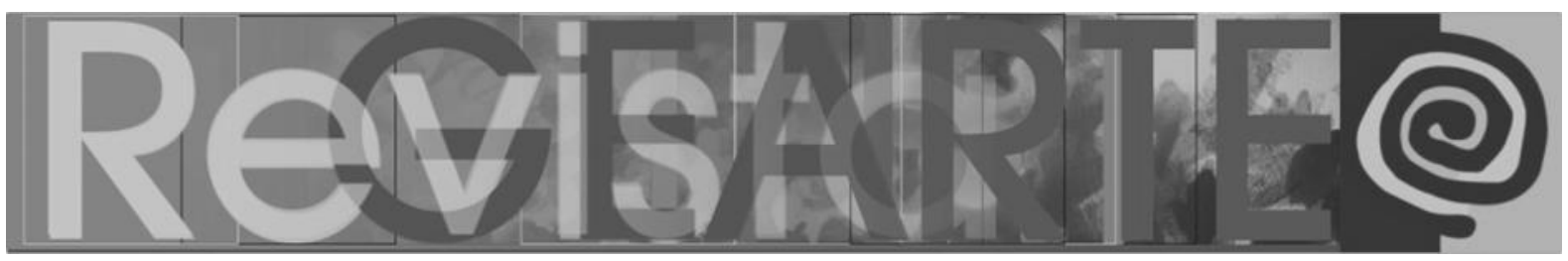

Pois, na arte, uma ideia só existe nas imagens que lhe dão forma, e a imagem existe como uma espécie de apreensão da realidade através da vontade, que o artista realiza de acordo com suas próprias tendências e as idiossincrasias de sua visão de mundo. (TARKOVSKI, 1998, p. 61).

O Fundo Nacional de Desenvolvimento da Educação (FNDE) do Ministério da Educação do governo brasileiro define as artes visuais como uma área extremamente ampla, que abrange qualquer forma de representação visual - cor e forma. Apesar da flexibilidade das fronteiras que determinam as artes visuais, geralmente são consideradas as formas de expressão que normalmente lidam com a visão como meio principal de apreciação. A definição feita pelo FNDE segue elencando quais artes geralmente são consideradas visuais: pintura, desenho, gravura, fotografia e cinema.

Hoje conhecida como a sétima arte, o cinema teve em sua trajetória teóricos que exploraram a linguagem fílmica como expressão artística. Um deles foi Tarkovski, que ao refletir sobre o significado da arte conclui que somente quando o diretor produz com sua visão própria e seu sistema particular de imagens é capaz de se deixar emergir como artista (TARKOVSKI, 1998, p. 68). Devemos refletir sobre a concepção de que "o tempo, registrado em suas formas e manifestações reais: é esta a suprema concepção do cinema enquanto arte" (TARKOVSKI, 1998, p. 72), pois, como nos fala Migliorin, a imagem é afetada e alterada pelo mundo, mas é, acima de tudo, ligada a ele, ao tempo e ao real (MIGLIORIN, 2011, p. 109).

É necessário entender o cinema como arte, pois é através dela que "o homem conquista a realidade mediante uma experiência subjetiva" (TARKOVSKI, 1998, p. 39). É esse o pontapé para que o cinema mostre suas outras dimensões: políticas, sociais e educacionais, para que produzir filmes seja ampliar, enriquecer e fortificar olhares e subjetividades. Mas também para que o fazer e o fruir do cinema mostrem suas possibilidades de incentivar a visão crítica particular, invenções coletivas e compartilhamento de experiências, colocando diversas vivências diante das potências sensíveis de um filme. "Necessidade da arte, urgência da democracia." (MIGLIORIN, 2011, p. 112). 


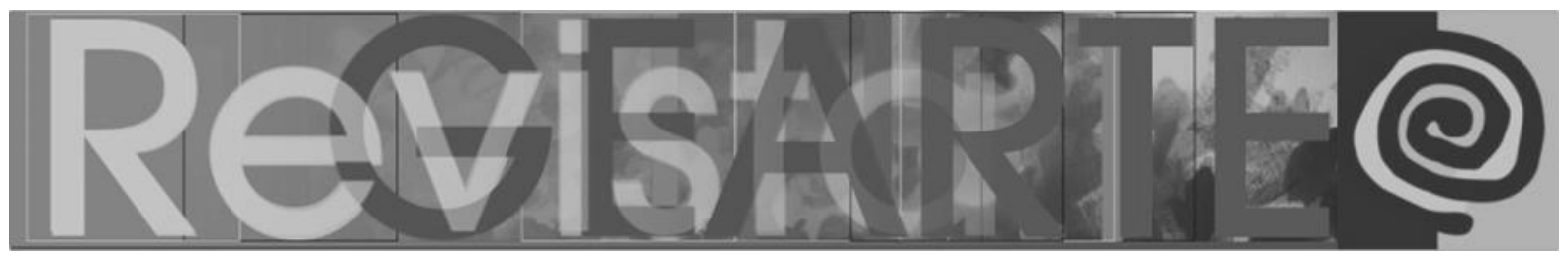

\section{A Interdisciplinaridade dentro do Partejar Potiguara}

O mundo é integrado. Todos os acontecimentos são intrinsicamente ligados e guardam correlação. A biologia nos explica que as fases da lua influenciam na agricultura. Um arco-íris é um fenômeno tanto meteorológico quanto óptico. As leis da física influenciam e são influenciadas pelos corpos sobre os quais atuam. A produção de arte, como a composição de músicas, é também um processo matemático. Separar os saberes é diminuir a capacidade de conhecer, compreende-los enquanto inter-relacionados é enxergar o mundo de forma holística.

O Partejar Potiguara, enquanto projeto de extensão interdisciplinar, trabalha essa união na dimensão política e cientifica dentro do contexto da universidade. A divisão de áreas e segregação dos grupos acadêmicos formam círculos separados que tentam ignorar questões que tangem as pesquisas e vivências desses indivíduos: os afetos e relacionamentos, questões de gênero, sexualidade e sentimentos, o meio ambiente, a vida cotidiana, o bem-estar físico e psíquico e diversas outras implicâncias as quais a grade curricular não se atém de forma contextual (FOUCAULT, 2000).

O ambiente acadêmico pouco ressalta a importância do bem-estar espiritual. A objetificação do professor nas estruturas tradicionais de educação promove uma cisão entre corpo e mente, como se alunos e professores não fossem seres íntegros e pudessem se desprender de sua parte interior ao entrar na sala de aula onde, supostamente, só se utilizaria da mente para cumprir o trabalho (hooks, 2013, p. 29). A interdisciplinaridade, dentro do contexto universitário, busca ressaltar a união de corpo, mente e mundo social como essencial para construção de saberes e compromisso com a educação. Para além das técnicas, regras, métodos e organizações, é compreender o mundo, as relações existentes nele e as nossas próprias relações dentro dele. 


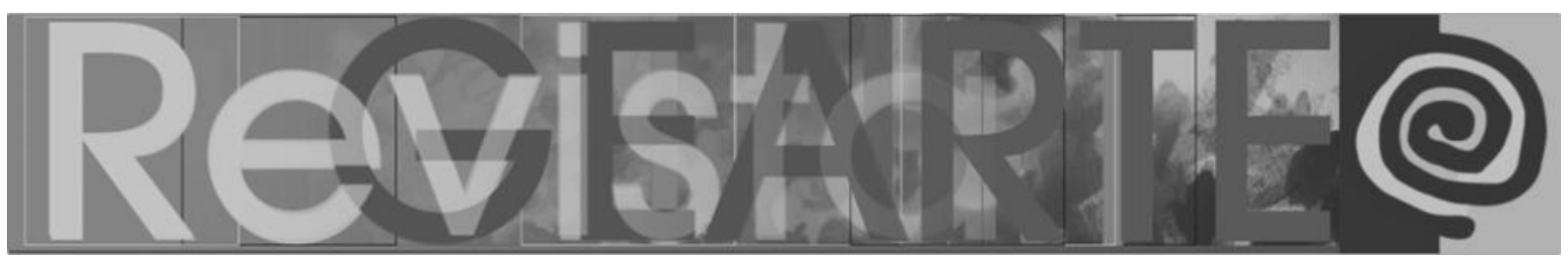

Para Morin (2002), mostrar a correlação entre as disciplinas e a complexidade das questões, desfragmentando-as, é a maior razão da educação. A universidade não deve isolar seus objetos do seu meio, nem as partes do todo do mundo. A interdisciplinaridade não tem por objetivo excluir a diversidade de domínios do saber, muito menos desmerecer os caminhos individuais de estudo e aprofundamento, mas sim diluir as fronteiras entre essas áreas, no intuito de produzir conhecimentos em cooperação, cada um podendo somar com suas especialidades e competências.

A interdisciplinaridade busca quebrar com a compartimentalização, ultrapassando a barreira dos conhecimentos enciclopédicos para uma construção coletiva, de afeto e partilha. Como nos projetos Partejar e CinEducar, promover diálogos que descontroem preconceitos, democratizam a informação e se importam com solucionar dúvidas, promovendo um espaço acolhedor que incentiva a independência e espírito crítico individual. Desde a responsabilidade de administrar a carga horária dentro das atuações dos projetos, enfrentar desafios ao longo do processo, abraçar a renovação diária dos pensamentos e questionamentos e, principalmente, perceber-se como sujeito afetante e afetado ciente dessa ciência unificada não só como peça importante no ensino, pesquisa e extensão, mas como via de engajamento político e social.

\section{Onde a antropologia encontra o cinema}

Desde o início dos projetos, o grupo debate sobre a impossibilidade de uma pesquisa ser imparcial, ainda mais quando realizada majoritariamente em campo, na prática que entrelaça afetos e uma grande diversidade de lugares de fala. Pensar a interdisciplinaridade na relação entre tantos saberes envolvidos é perceber que a união de todas elas não forma um discurso uníssono, mas justamente complexo. A pesquisa, processamento de dados e a ciência em si são atravessados por olhares e vivências daqueles que interagem e a produzem. "Nossas maneiras de conhecer são forjadas pela história e pelas relações de 


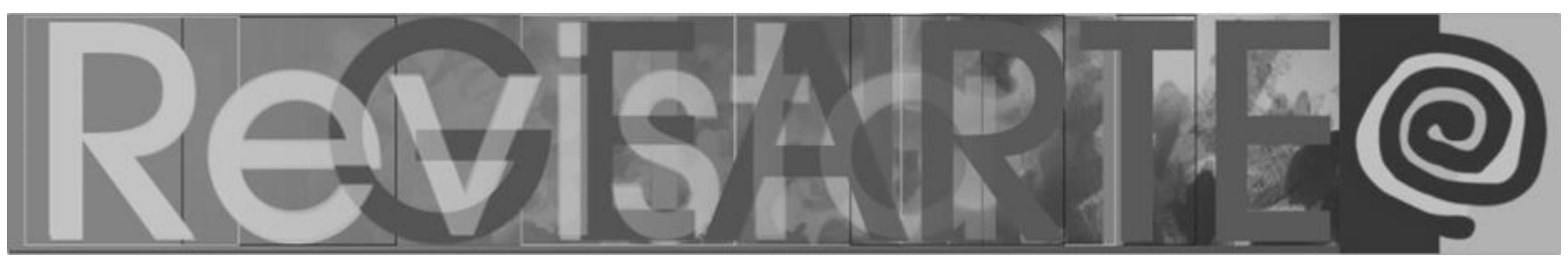

poder" (hooks, 2013, p. 46). As discussões despertadas pelo campo da antropologia ajudam a concluir que quaisquer reflexões despertadas durante o estudo são resultados apenas possíveis através da nossa visão múltipla e, ao mesmo tempo, particular a partir do contato com o conteúdo do que é posto em experimento.

Assim, é fundamental compreender as variáveis dos encontros com as mulheres indígenas que iriam influenciar a condução dos estudos teóricos: desde a forma de adentrar na comunidade, passando pela forma de se relacionar com ela, até a forma com que cada individualidade estava se afetando e processando aquelas vivências. Um ponto muito importante a ser levado em consideração no estudo é o fato de que mulheres indígenas, assim como mulheres negras, sofrem de uma dupla opressão e vulnerabilidade, sobre a qual Djamila Ribeiro fala em seu livro, ao refletir sobre a perspectiva de Lélia Gonzales: além do sexismo, há também o racismo. Essas mulheres, além de não terem suas vozes legitimadas nos espaços comuns, também não recebem a devida atenção sobre suas realidades dentro dos movimentos. No movimento indígena, há pouco, ou quase nenhum, debate sobre a opressão contra a mulher, e no movimento feminista há pouco, ou quase nenhum, debate sobre a opressão racial.

Somente basear as análises no capitalismo patriarcal não dava conta de responder às situações de mulheres negras e indígenas da América Latina, pois, para a autora, faltava incluir outro tipo de discriminação tão grave quanto as outras citadas: a opressão de caráter racial. (RIBEIRO, 2017, p. 17).

O Partejar Potiguara teve um início definido, mas a pesquisa teórica e a necessidade do CinEducar, não. O encontro entre o conhecimento acadêmico e a sabedoria popular ancestral gerou uma potência científica, uma inquietação teórica, atravessada pela troca de experiências, repertórios e afetos entre pessoas, em que cada uma possui sua própria história e subjetividade e pertencimentos identitários múltiplos. O grupo se deparou com uma questão corriqueira nos estudos da antropologia: "Como estudar processos acompanhando movimentos, 


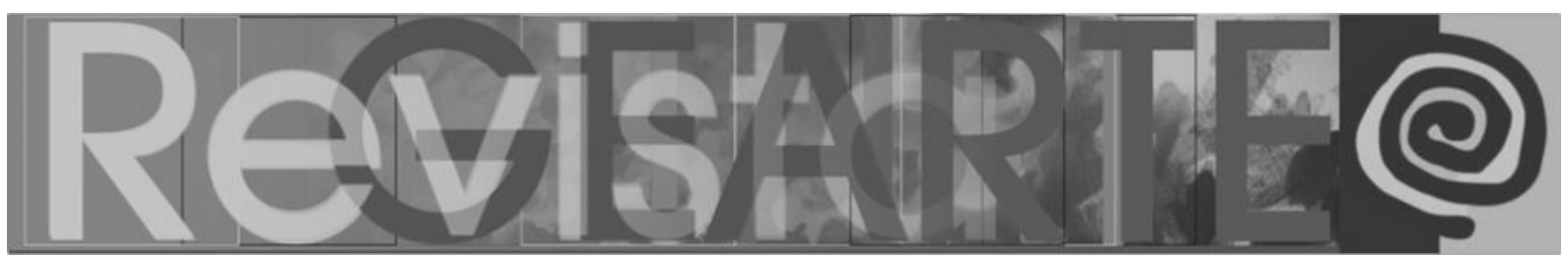

mais do que apreendendo estruturas e estados de coisas?" (PASSOS; KASTRUP; ESCÓSSIA, 2009, p. 8). Dentre tantos métodos de pesquisa qualitativa, quantitativa, estruturada, nenhum se encaixava com o caráter processual da pesquisa.

O processo, como um sistema acêntrico, não poderia se utilizar das metodologias habituais que traçam um caminho certo destinado ao fim. Em um plano de composição heterogênea suscetível a mutações, é preciso não abrir mão do rigor científico, mas ressignificá-lo. Ater-se não mais à exatidão, mas ao compromisso e interesse de explorar a realidade em que se insere como uma intervenção (PASSOS; KASTRUP; ESCÓSSIA, 2009, p. 11). É a consciência do pesquisador de entrar em campo sabendo das implicações que sua presença gera nas vivências e disposto a trabalhar com as variáveis do caminho.

\begin{abstract}
O cartógrafo se encontra sempre na situação paradoxal de começar pelo meio, entre pulsações. Isso acontece não apenas porque o momento presente carrega uma história anterior, mas também porque o próprio território presente é portador de uma espessura processual. (DE BARROS; KASTRUP, 2009, p. 58).
\end{abstract}

Tal qual o conceito de rizoma de Deleuze, que, como explicam Cabral e Borges (2006, p. 10), é uma combinação anômala, sem início ou fim, apenas meios cujos resultados não podemos prever, a pesquisa é essa circulação de estados feita de direções móveis. Nas visitas às aldeias, havia um raso mergulho por parte da comunidade universitária na vida da comunidade Potiguara, cientes de que não seria possível compreender nem, muito menos, capturar a totalidade de sua realidade. À medida do andamento do projeto de extensão, se tornou essencial por parte da equipe deixar que ele tomasse seus próprios rumos a partir dos imprevistos encontrados no caminho que o colocavam em direções inesperadas. É fundamental perceber a pesquisa como um organismo vivo orquestrado pela vivência entre os sujeitos, alimentado pelos afetos gerados com essas vivências e que, como bem exemplificam os casos apresentados neste texto, devolve em troca o resultado da equação que envolve todas essas variáveis. 


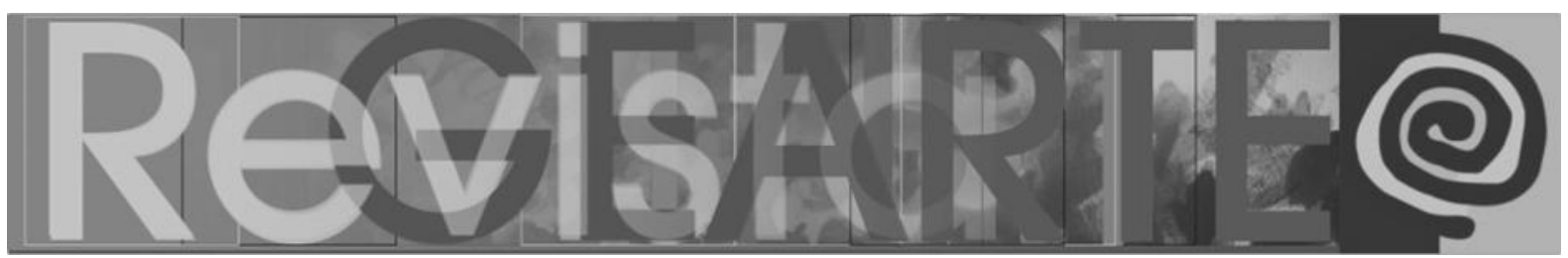

Para o antropólogo Malinowski, segundo Barbosa (2006, p. 11), a pesquisa de campo permite uma convivência intensiva que, a partir da comparação entre o que é dito pelos pesquisados com o que é visto durante a pesquisa, resulta em um rico material sobre a vida do grupo observado. Esse material se enriquece ainda mais quando, na pesquisa, o pesquisador é também observado e nesse sistema de troca de vivências o material coletado passa a ser uma construção coletiva, sendo que nenhum dos lados está isento. Tanto ele quanto Robert Flaherty, um cineasta norte-americano e um dos precursores do filme documentário, acreditavam que a história a ser contada emergia a partir do material do convívio de campo. "Havia então grande consciência da pessoa como indivíduo único e da importância de falar sobre as culturas por meio de seus sujeitos e de suas práticas." (BARBOSA, 2006, p. 13). No Partejar, essa questão é potencializada, pois o sujeito não é só o meio, mas também quem fala.

É aqui que a antropologia e o ensino de cinema se encontram. Seja na necessidade da antropologia em se utilizar do cinema para registrar em imagens a atuação em campo a fim de armazenar ou comprovar o estudo, seja na necessidade do cinema em se utilizar da antropologia para que os seus registros tenham a consciência social necessária e o cuidado com o que está sendo documentado, para não reproduzir relações de poder tão enraizadas. Os debates que transitam nessa conexão se retroalimentam na reflexão sobre mediação e lugar de fala: os limites do discurso a partir do ponto de vista de quem está o construindo. Falar sobre lugar de fala é uma discussão estrutural que não diz só sobre a experiência de indivíduos, mas das condições sociais que permitem que esse grupo de indivíduos acesse espaços de cidadania ou que tenham suas oportunidades restringidas. A falta de acesso à universidade, a espaços de saberes legitimados, a meios de comunicação, à política institucional, por exemplo, acarreta a não produção teórica desses indivíduos, a ausência de suas epistemologias nesses espaços e a não propagação de suas vozes (RIBEIRO, 2017, p. 35). 


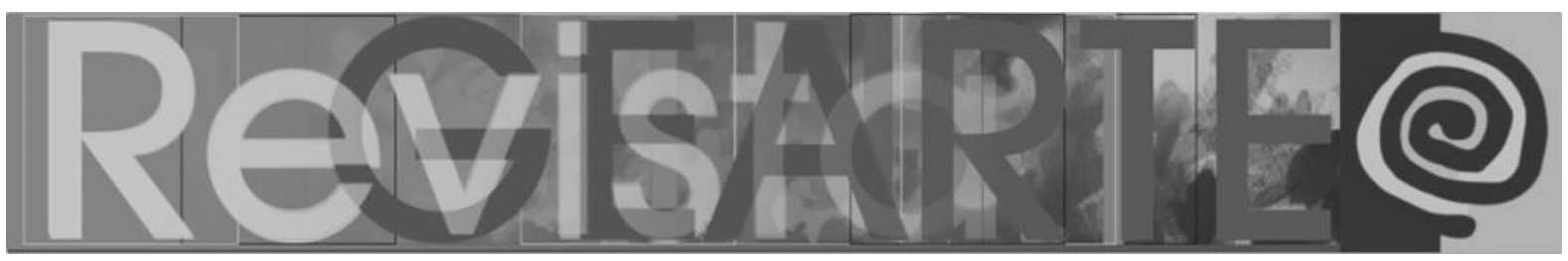

O falar não se restringe ao ato de emitir palavras, mas de poder existir. Pensamos lugar de fala como refutar a historiografia tradicional e a hierarquização de saberes consequente da hierarquia social. Quando falamos de direito à existência digna, à voz, estamos falando de locus social, de como esse lugar imposto dificulta a possibilidade de transcendência. (RIBEIRO, 2017, p. 37).

Encontramo-nos corroborando com o que defendia Jean Rouch, um realizador francês, etnólogo e teórico do filme documentário, que também estudava a relação direta entre essas duas áreas. Para ele, o mais importante não era descrever a realidade observada, mas sim realizar com o grupo estudado um diálogo contínuo potencializado pelo cinema "que, como linguagem, poderia ajudar a pensar a prática etnográfica e, por conseguinte, a própria antropologia" (BARBOSA, 2006, p. 20).

\section{O cinema engajado}

O objetivo do Partejar Potiguara e do CinEducar, então, é entender como a antropologia pode ajudar no ensino de cinema e na compreensão de como fazer uma aproximação etnológica cuidadosa de troca de saberes. Como falar de produção para cinema, que parece ser algo restrito a centros urbanos, com quem provavelmente não possui intimidade com a linguagem audiovisual de viés mais autoral, engajado, artístico ou expressivo? O grupo visou a apresentar o cinema como espaço coletivo e popular, de ocupação necessária, para que histórias das mais diversas fossem contadas e que narrativas legítimas de si ganhassem formas e expressão.

A visibilidade pública daquilo que atravessa suas existências é almejada por vários grupos da sociedade civil com objetivo de que seus interesses sejam enxergados e se tornem parte legítima do corpo social e do debate político. Esse desejo pela visibilidade está cada vez mais perpassado nas artes pelo discurso do direito à autorepresentação, "a possibilidade de indivíduos e coletivos da periferia de exercer maior controle sobre suas próprias representações, de modo a refutar aquelas consideradas 'erradas' ou não-satisfatórias” (ZANETTI, 2008, p. 8). 


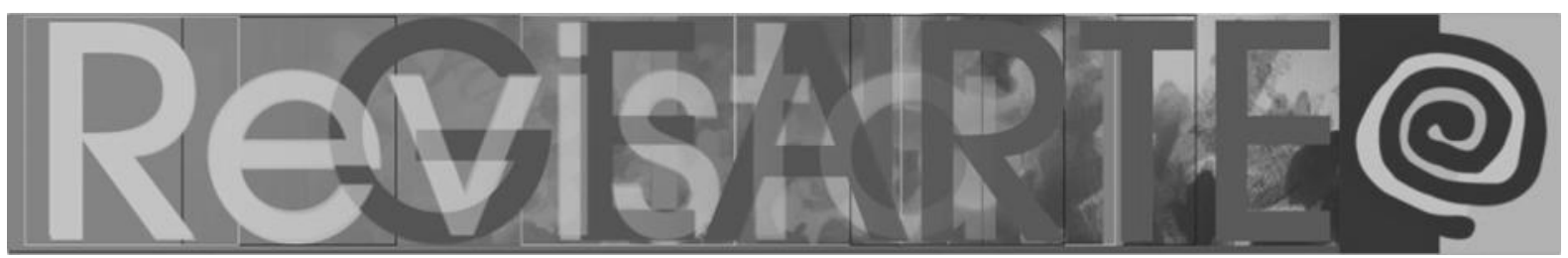

Como fala Mogadouro (2016, n. p.), desde o princípio a história da população indígena foi contada de forma estereotipada, no início pela literatura e depois pelo cinema, a partir da visão do branco que valorizou a aculturação e dizimação feita com os índios, colocando-os como vilões da história, representando-os como bárbaros ou pouco inteligentes, além de anulando sua diversidade. Isso promoveu uma visão estereotipada da figura do índio, que o perpetua como idiotizado a partir do preconceito. "Grupos historicamente marginalizados normalmente não têm controle sobre sua própria representação" (SHOHAT; STAM, 2016, apud ZANETTI, 2008, p. 8). Essa problemática é potencializada quando falamos do grupo social das mulheres indígenas, que sofrem duplamente essa opressão. Sendo silenciadas nos dois espaços de existência, enquanto mulheres e enquanto indígenas, dificilmente têm controle sobre as representações que são feitas sobre si.

Desde a origem do cinema brasileiro que os povos indígenas são representados em filmes que, em sua maioria, contribuem para a perpetuação de um ponto de vista dominante etnocêntrico que, além de excluir as particularidades, segue colocando os indígenas em um passado histórico e na figura de selvagens, preguiçosos e exóticos (CUNHA, 2000, apud NUNES; DA SILVA; SILVA, 2014, p. 3). Foi só perto dos anos oitenta que tivemos as primeiras obras audiovisuais que discutiram a exploração e abuso sofridos pela população indígena, quando surgiram novos filmes com intenção de reverter essas raízes históricas de julgamento. Como por exemplo Iracema: uma transa amazônica, de 1981, que faz uma crítica a partir de sátira sobre a exploração indígena desde a invasão dos civilizados (MOGADOURO, 2016, n. p.).

Os estereótipos cristalizados no imaginário popular e as representações errôneas são sinais vivos dos resquícios do colonialismo, massacre, escravidão e assimilação que permeiam a história dos povos indígenas no Brasil.

É profundo o medo de que qualquer descentralização das civilizações ocidentais, do cânone do homem branco, seja na realidade um ato de 


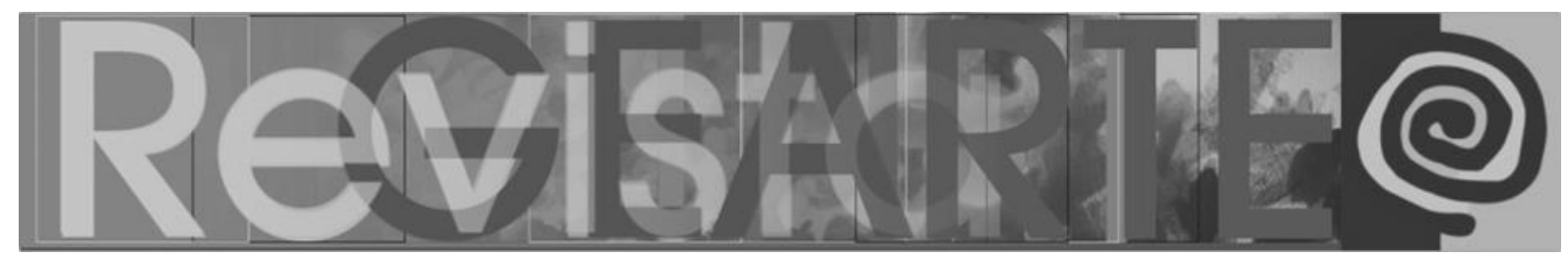

genocídio cultural. Certas pessoas acham que todos os que apoiam a diversidade cultural querem substituir uma ditadura do conhecimento por outra. (hooks, 2013, p. 49).

"O movimento cinemanovista ${ }^{5}$ abre as portas para se pensar o nacionalismo de um ponto de vista popular, indígena e negro, isto é, da perspectiva das minorias em face de suas tensões com as classes dominantes econômica e politicamente" (NUNES; DA SILVA; SILVA, 2014, p. 7). O debate que surge, após, diz respeito à escassez de produções feitas a partir da perspectiva dos próprios indígenas.

"Da publicidade ao YouTube, da tevê ao elevador, somos exploradores de naturezas eletrônicas, coloridas, ruidosas" (MIGLIORIN, 2011, p. 108), representatividade é nos ver espelhados nesses lugares comuns, que naturalmente exploramos e pelos quais diariamente estamos cercados. Ter a oportunidade de ver nossas pautas coletivas sendo abordadas, a partir de nossos lugares de fala, nossas aparências e modos de vida sendo representados de modo realista, isento de preconceitos. Os grupos fora dos padrões culturais coloniais (e neocoloniais) hegemônicos dominantes pouco têm essa oportunidade e lutam para encontrar "frestas" para falar sobre si.

\begin{abstract}
Na sociedade midiática, somos submetidos a uma invasão de privacidade cotidiana pelos meios de comunicação e informação, que forjam identidades sociais, sugerindo insidiosamente, às pessoas, conceitos daquilo que elas anseiam e almejam a ser, identidades visuais que tendem a ser consideradas como universais, estáveis e indispensáveis. Uma espécie de adestramento que consagra certas formas de falar, ver e estar no mundo. (COSTA; MARTINS, 2012, p. 190).
\end{abstract}

Atualmente os cinemas de borda ${ }^{6}$ e de periferia ${ }^{7}$ promovem ações de enfrentamento e ocupação de espaços, na tentativa de ampliar essas frestas. Com

5 Movimento cinematográfico brasileiro dos anos 60 e 70 de questões ligadas à realidade nacional e com ênfase na igualdade social.

6 Produzido por realizadores autodidatas, moradores de cidades pequenas ou de arredores das grandes capitais. Esses filmes são produtos adaptados às regiões, ao modo de vida e ao imaginário popular e massivo das comunidades envolvidas no processo de sua produção.

7 Movimento de produção audiovisual de periferia, que promovem um discurso pautado pelo direito à autorrepresentação. 


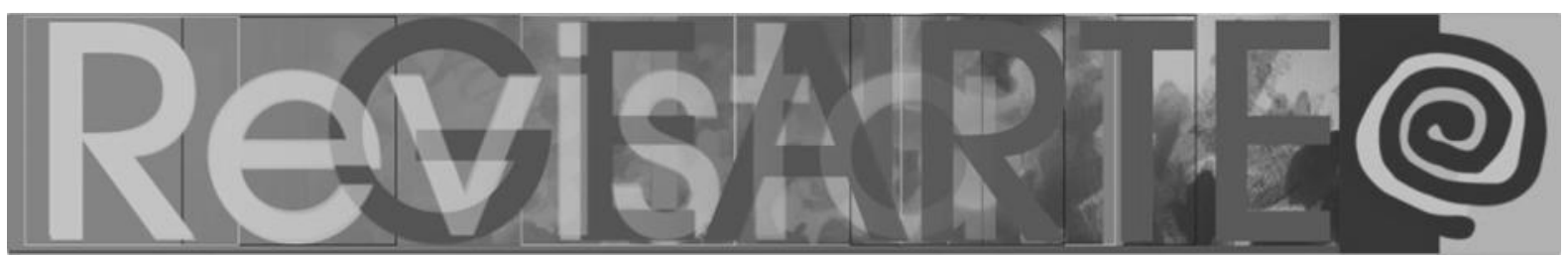

festivais de cinema próprios e cada vez mais produções cinematográficas, querem atingir espectadores para mostrar que comunidades marginalizadas têm histórias para contar como protagonistas. Festivais como o Cine Cufa, uma iniciativa da Central Única das Favelas do Rio de Janeiro, propõem uma nova ordem cultural e artística, invertendo as posições de representação. No texto de apresentação do evento do ano de 2007, falam sobre incentivar o ponto de vista de que a periferia tem capacidade de contribuir não só com personagens, mas com protagonistas, fazendo com que os realizadores desses filmes se identifiquem como representantes de "um novo e legítimo movimento estético, social e político" (CINECUFA, 2007 apud ZANETTI, 2008, p. 2)

O cinema indígena aos poucos também está promovendo essas ocupações. Seja através de espaços dedicados dentro de festivais maiores, como é a Mostra Territórios Audiovisuais Indígenas dentro do Festival de Brasília do Cinema Brasileiro, seja com evento exclusivo, como a Mostra Cinema Tela Indígena, que aconteceu em 2019 na cidade de Porto Alegre (RS). Algumas iniciativas, como o Festival Cine Kurumin, uma mostra competitiva que conta com apoio do Estado da Bahia, refletem ainda sobre a necessidade de incentivo à ocupação desses espaços por mulheres e promovem uma categoria dedicada às suas produções: a mostra Cinema das Mulheres Indígenas.

Outra iniciativa poderosa foi que, em 2019, para comemorar o Ano Internacional das Línguas Indígenas ${ }^{8}$, a Unesco ${ }^{9}$ disponibilizou no YouTube um acervo de 92 produções audiovisuais que abordam a diversidade linguística e cultural indígena. $\mathrm{O}$ chamado Festival de Cinema Indígena Online ${ }^{10}$, é parte de uma ação maior que visa a reiterar as línguas indígenas como fontes valiosas de saberes e seu empoderamento como caminho para assegurar a paz, como

8 Site do projeto: https://en.iyil2019.org/

9 Organização das Nações Unidas para a Educação, a Ciência e a Cultura.

10 Link para acesso à playlist criada no Youtube com as obras: https://www.youtube.com/playlist?list=PLWuYED1WVJIN2UN_XKOKpTvDXv_N520C2

LUCENA, Micaelle Lages; VALLE, Isabella Chianca Bessa Ribeiro do. CinEducar e Partejar Potiguara: 388 o ensino do cinema para mulheres indígenas como ferramenta de (r)existência. Revista GEARTE, Porto Alegre, v. 7, n. 2, p. 372-400, maio/ago. 2020.

Disponível em: http://seer.ufrgs.br/gearte 


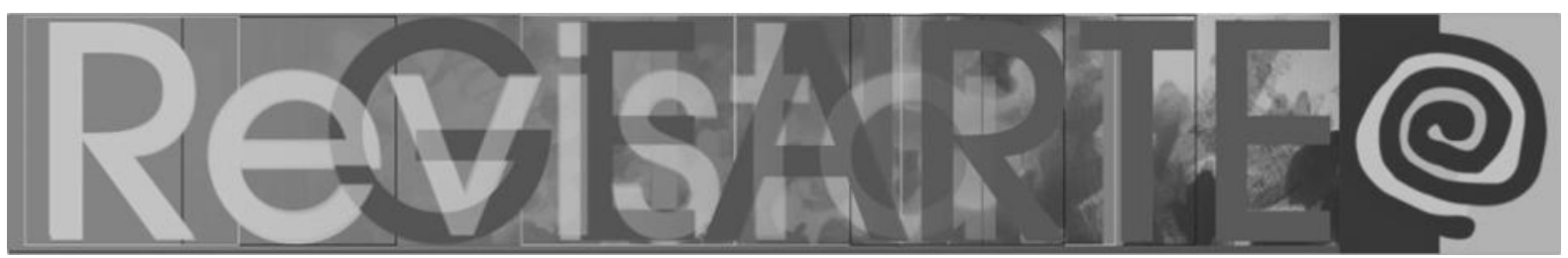

instrumento de inclusão, de reconciliação de sociedades e como forma de assegurar direitos e diversidade.

Caminhar ao lado desses movimentos de ocupação e empoderamento é direcionar o conhecimento acadêmico para o intuito de amplificar essas vozes e ser um suporte que mostra como o cinema pode ser expressão artística, vazão de discursos e até mesmo mercado de trabalho para todas as populações.

Jean Rouch defendia o autor do filme como construtor da realidade fílmica, acreditando na "utilização do filme como uma forma de contar e expressar coisas que não poderiam ser expressas de outra forma, principalmente o imaginário que povoa a vida dos indivíduos em seu contexto de vida" (BARBOSA, 2006, p. 19). Conhecimento é poder e, assim como aprender a ler e escrever liberta, aprender a ler e compor imagens é libertação e empoderamento. É autonomia para escrever sua própria história e tecer sua própria representação dentro do mundo mostrado. É autorrepresentação, uma reflexão sobre como a pessoa enxerga sua própria identidade e também o espaço a que pertence. É lugar de fala, autoria para contar, a partir de suas vivências, sobre os saberes e cultura do seu grupo.

E foi a partir dessa compreensão que os projetos Partejar Potiguara e CinEducar encontraram no cinema uma ferramenta capaz de registrar olhares e memórias, de se encarregar da perpetuação dos saberes que se construíam em campo, mas, principalmente, de luta política e social.

\section{Educação como prática da liberdade}

"Ensinar com o cinema passa, justamente, por um "não saber" das partes que se preparam para o acontecimento, ou seja, para a invenção intempestiva consigo e com o outro, com as imagens, mundos e conexões que o cinema nos permite." (MIGLIORIN, 2011, p. 110).

Ajudar na promoção da autonomia é estar em conjunto com movimentos decolonialistas. O Partejar Potiguara promoveu, nas aulas de cinema com 


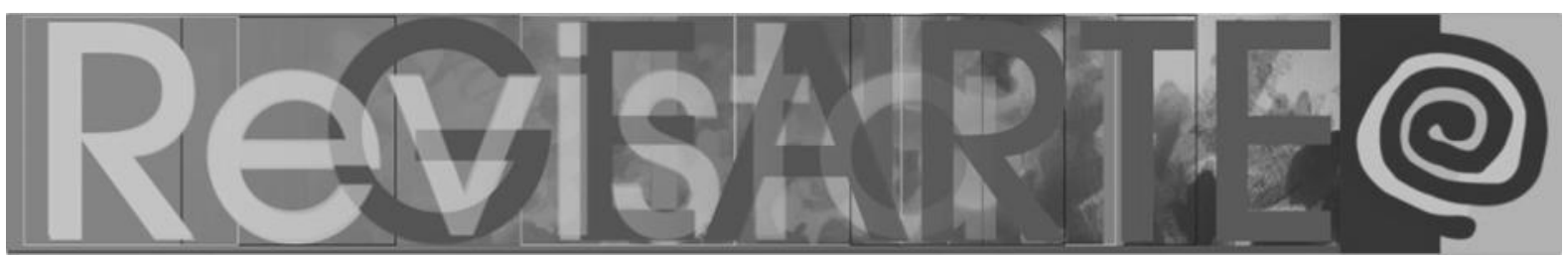

mulheres indígenas, não só um diálogo com troca de saberes onde todas as partes se enriqueceram de conhecimento, mas também um impulso primário que despertou desejos de se produzir cinema a partir dos pontos de vista da própria comunidade implicada no conteúdo. Para isso, foi preciso disposição para ler sobre, além de cinema, teorias da educação, antropologia, saúde, entre outros campos que atravessavam a prática do projeto, e desenvolver suas próprias metodologias a partir delas. Tudo isso provocou o próprio surgimento do CinEducar.

O sistema de poder que perpetua a estrutura de preconceito já falado é o mesmo que se empenha na manutenção do sistema educacional tradicional. Esse, que foi regido pela burguesia norte-americana no século XIX e de métodos que se limitam a técnicas de memorização e transferência de conhecimentos (PEREIRA et al., 2009, p. 155), ainda prevalece na nossa vida cotidiana. Manter esse sistema é permitir a continuação desses valores tradicionais pautados pela dominação. Os interessados nisso "nos ensinam a crer que a dominação é 'natural', que os fortes e poderosos têm o direito de governar os fracos e impotentes" (hooks, 2013, p. 43). Ir contra é uma luta política que pode ser lutada através da arte.

Durante as aulas do Partejar Potiguara, rompia-se com um sistema de ensino que trabalha para reforçar a dominação a fim de promover a democracia da ferramenta cinematográfica. Assim como hooks (2013) fala, é necessário desaprender o racismo para aprender sobre descolonização para "compreender plenamente a necessidade de criar uma experiência democrática de aprendizado das artes liberais" (hooks, 2013, p. 55).

bell hooks inclusive foi uma das teóricas estudadas no CinEducar. Professora, autora, ativista, negra e feminista estadunidense, fortemente inspirada por Paulo Freire, ela defende uma educação transgressora que valorize a subjetividade e liberte os sujeitos de ciclos de exploração e opressão. O Partejar, associado ao CinEducar, visou a incorporar esses fundamentos na sua prática de 


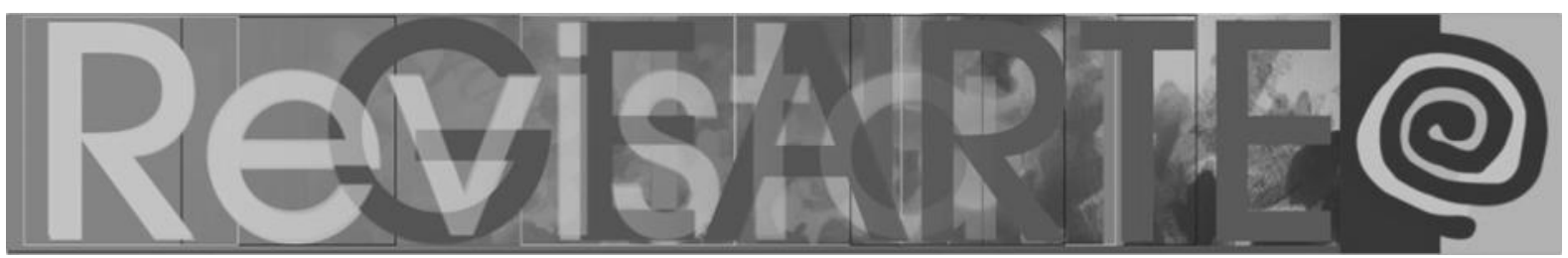

ensino, como a política da Escola Progressista de Dewey, que "partia do princípio de que a escola deveria atuar como um instrumento para a edificação da sociedade através da valorização das qualidades pessoais de cada indivíduo" (PEREIRA et al., 2009, p. 155).

"A postura deles, do professor e do aluno, é dialógica, aberta, curiosa, indagadora e não apassivada, enquanto fala e enquanto ouve. O que importa é que professor e alunos se assumam epistemologicamente curiosos." (FREIRE, 1996, p. 33). hooks, em sua obra, corrobora o ideal de Freire ao discutir que a educação só pode ser libertadora, como almejada pelos projetos, "quando todos tomam posse do conhecimento como se este fosse uma plantação em que todos temos de trabalhar" (hooks, 2013, p. 26). Assim, o plano de aulas do Partejar Potiguara buscou promover o diálogo, para criar um ambiente mais descontraído onde a informação pudesse ser trocada sem regras rígidas. As aulas iriam misturar partes teóricas com práticas, entendendo que "arte não se ensina, se experimenta" (BERGALA, 2008, apud MIGLIORIN, 2011, p. 110).

A primeira etapa da execução do planejamento era recrutar alunas. Desde o início compreendia-se que seria um desafio encontrar o público-alvo de interessadas dentro da comunidade. Os projetos fizeram contatos dentro da aldeia, convidando adolescentes em suas casas e visitando escolas da comunidade, pensando o processo e reformulando sempre que necessário. Até que foi sugerido e decidido colocar cartazes pela cidade e, para isso, as integrantes dos projetos contaram com a ajuda das mulheres indígenas envolvidas em outras áreas do projeto Partejar, às quais também foi solicitado que trouxessem suas sobrinhas, filhas, netas e vizinhas para conhecerem a ideia das aulas de cinema.

A partir daí, em um primeiro encontro, reuniram-se mais de 20 mulheres, entre adolescentes de 13 anos até estudantes de universidade e inclusive algumas mulheres com seus filhos. Agora o desafio do projeto passou a ser despertar interesse para que elas tivessem a vontade de continuar comparecendo às aulas, 


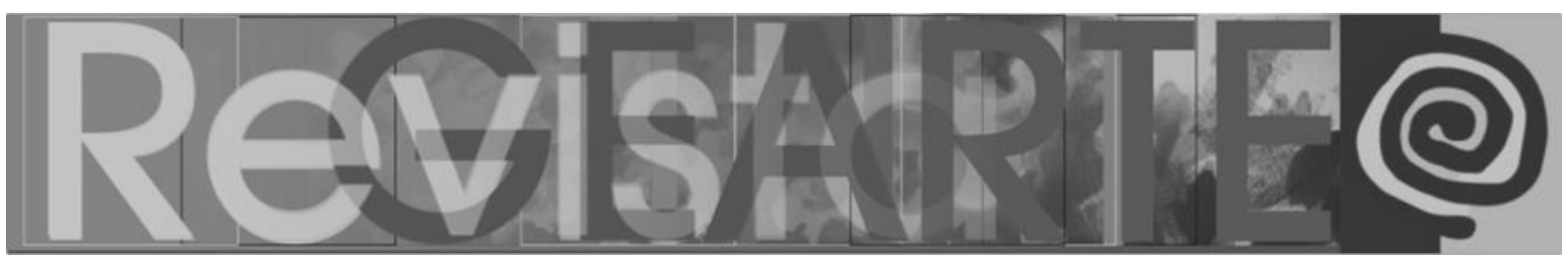

que seguiram mais como conversas em que buscou-se conhecer cada uma delas com bastante atenção, no intuito de não as ver como meras receptoras de informação, mas como seres dotados de emoções, histórias e vontades.

As aulas traziam dinâmicas com o objetivo de descontrair o espaço e estreitar os laços. "A sala de aula deve ser um lugar de entusiasmo, nunca de tédio" (hooks, 2013, p. 16), mas esse entusiasmo depende de um esforço coletivo, de tirar dos ombros do professor o peso de que ele é o único responsável pela dinâmica de sala de aula (hooks, 2013, p. 18). Percebeu-se ainda durante as primeiras aulas que muitas não estavam interessadas em estar lá, pois não sentiam afinidade com a linguagem audiovisual. De fato, aulas de cinema duas vezes por mês aos sábados de manhã não é uma proposta animadora para quem não tem tanto desejo.

Posteriormente, quando muitas começaram a faltar as aulas, foram procuradas individualmente, sem pressão, para que soubessem que suas faltas eram sentidas pela turma. Nessas conversas, o grupo descobriu que muitas têm no sábado o dia de acordar cedo e fazer os serviços do lar, outras têm no sábado o único dia livre para passear, viajar e se divertir e algumas gostavam de usar esse dia para dormir até tarde. Seus interesses pela produção de filmes precisariam ultrapassar esses outros atravessamentos para que elas seguissem comparecendo às aulas.

O espaço de sala de aula começou como uma oportunidade de troca entre várias mulheres infinitamente diferentes, que a partir do contato transformaram umas às outras, entre alunas e professoras, a presença de singularidades gerou debates únicos através do Partejar Potiguara, assim como a própria evasão gerou reflexões importantes sobre questões diversas, como as de gênero, dentro da comunidade. Como fala hooks (2013), não se pode ter um esquema de aulas rígido, precisa-se compreender a realidade e as necessidades daquele com quem 


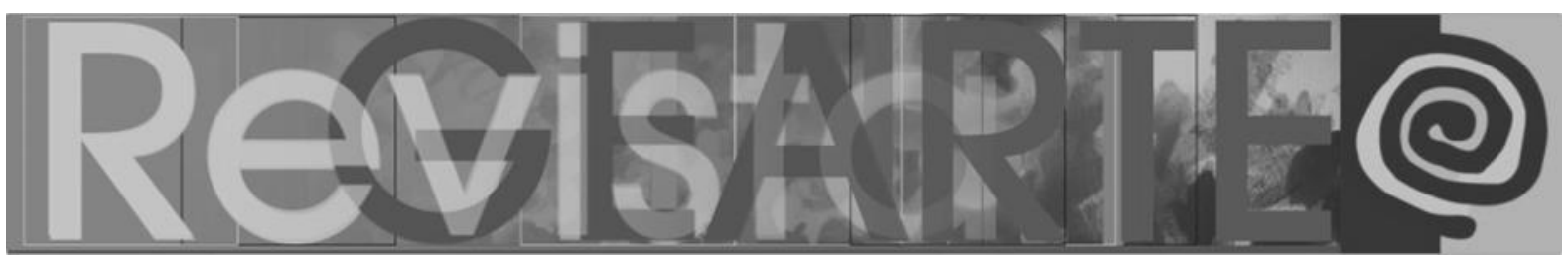

se lida. Entender qual abordagem vai ter maior apreço onde o assunto está sendo discutido.

Para lecionar em comunidades diversas, precisamos mudar não só nossos paradigmas, mas também o modo como pensamos, escrevemos e falamos. A voz engajada não pode ser fixa e absoluta. Deve estar sempre mudando, sempre em diálogo com um mundo fora dela. (hooks, 2013, p. 22).

Durante as aulas do Partejar, ficou claro que levar slides e apresentar nomes técnicos vindos da academia pouco importavam enquanto metodologia de ensinoaprendizagem. $O$ interesse era pelos exercícios práticos e pelas reflexões que partiam deles.

Muito foi pesquisado no projeto também sobre como exercer uma educação realmente libertadora em relação aos equipamentos utilizados. Foram dispensadas as câmeras ditas profissionais, que logo foram trocadas pelos telefones celulares de cada uma, já que depois elas não teriam acesso a outro tipo de equipamento para continuar produzindo.

A atualidade de celulares e dispositivos portáteis com acesso à internet trouxe essa possibilidade. É uma alternativa que instrumentalizou ainda mais a produção de conteúdos e também a difusão deles. E, possuindo uma câmera, é potencial para produção de filmes.

Nos primeiros encontros foram experimentados princípios da fotografia estática, que elas já tinham mais familiaridade por gostarem de fotografar e postar em redes sociais. Esses conceitos serviram de base para que elas adentrassem na produção das imagens em movimento: o vídeo. Em metade da aula conversavase como produzir um discurso audiovisual visualmente apelativo ou como contar alguma história não verbalmente. Depois colocava-se em prática, sempre com auxílio das facilitadoras à atividade.

Além de as atividades práticas terem uma aderência maior, as alunas só compreendiam a teoria quando em campo. Os conceitos turvos de dentro da sala 


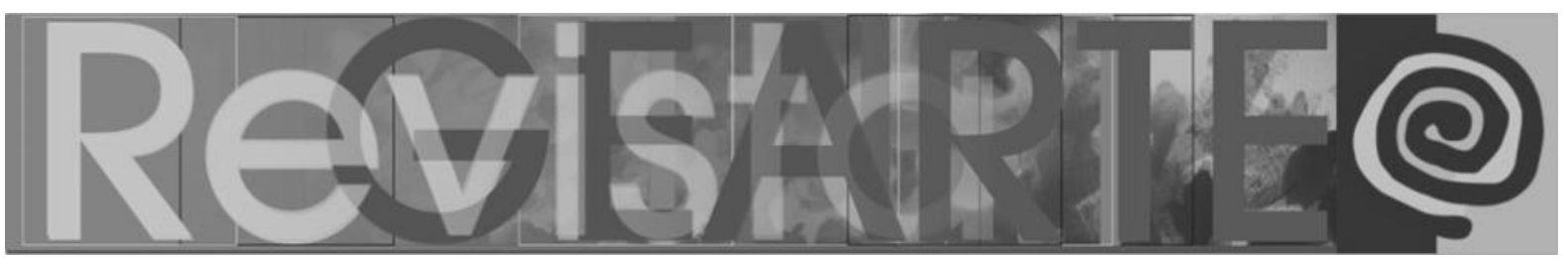

de aula se esclareciam ao surgirem dúvidas durante a execução das fotografias. A essas atividades foi dado o nome de desafios, já que o intuito era que elas explorassem como aplicar esses conceitos da teoria no mundo real e produzir um conteúdo inovador, acreditando que "a ideia básica do pensamento do teórico sobre a educação está centrada no desenvolvimento da capacidade de raciocínio e espírito crítico do aluno" (PEREIRA et al., 2009, p. 155).

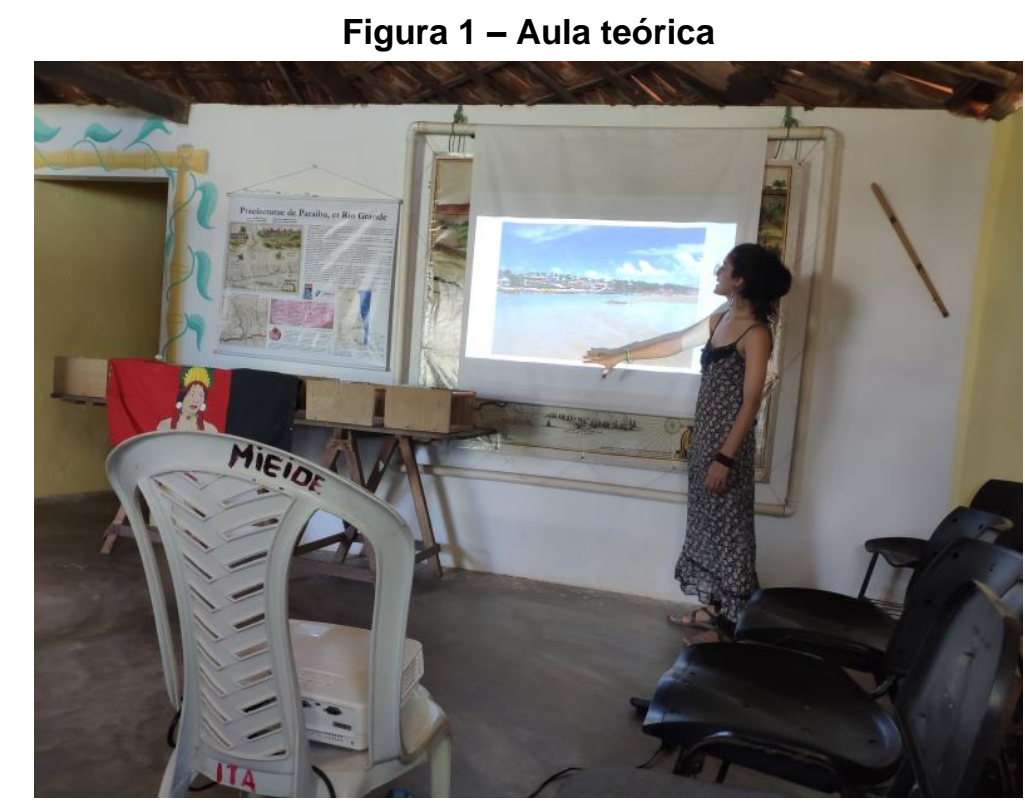

Fonte: Arquivo das autoras.

Figura 2 - Atividade prática de fotografia

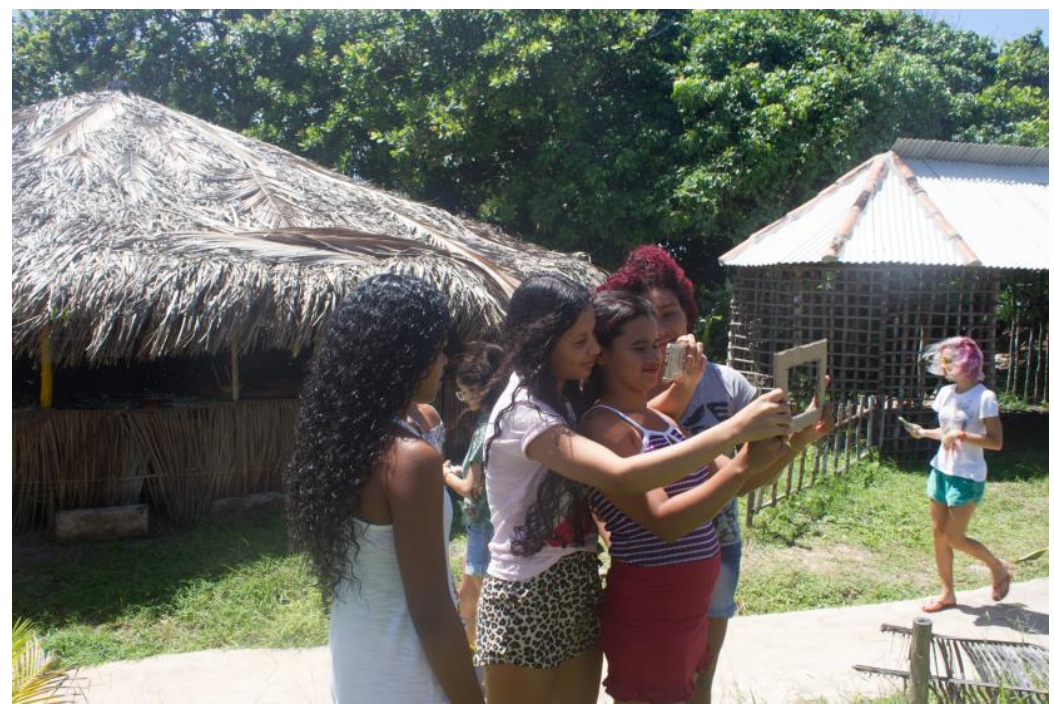

Fonte: Arquivo das autoras.

LUCENA, Micaelle Lages; VALLE, Isabella Chianca Bessa Ribeiro do. CinEducar e Partejar Potiguara: o ensino do cinema para mulheres indígenas como ferramenta de (r)existência. Revista GEARTE, Porto Alegre, v. 7, n. 2, p. 372-400, maio/ago. 2020.

Disponível em: http://seer.ufrgs.br/gearte 


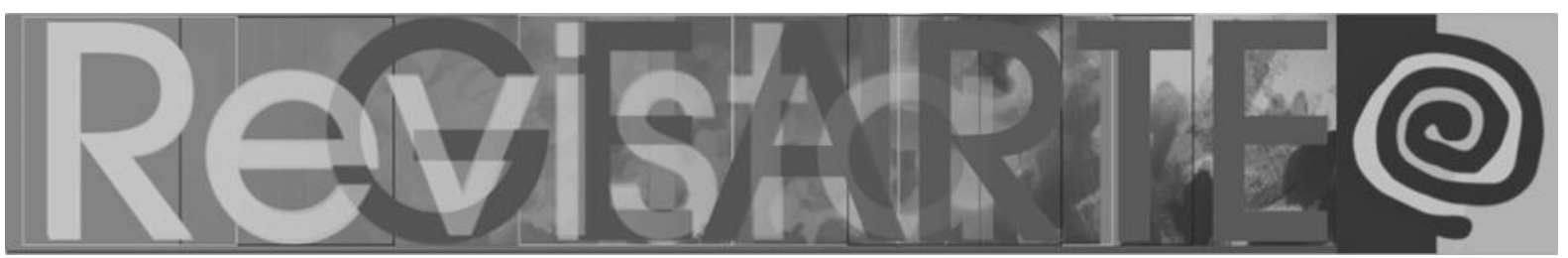

Figura 3 - Atividade prática de filmagem

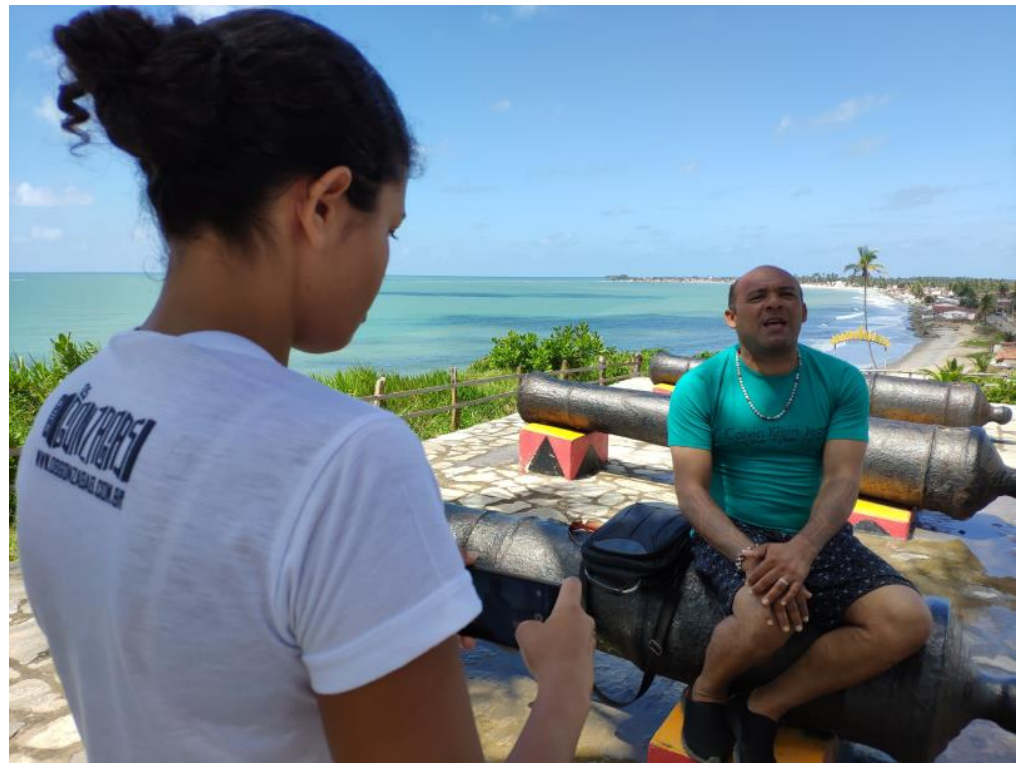

Fonte: Arquivo das autoras.

hooks (2013, p. 60) falava que adotar novas formas de compartilhar conhecimento é um desafio e demora até que os alunos consigam encarar esse desafio como algo positivo. Algumas alunas ficavam confusas com a autonomia dada para expressar suas próprias ideias e simplesmente diziam que não sabiam fazer, por medo de que existisse o conceito de certo e errado dentro da execução das atividades. Essa etapa foi vista como parte do processo de desconstrução contínua dos métodos tradicionais.

Por outro lado, após as atividades práticas, quando eram propostos diálogos mais profundos na sala de aula, cuja intenção é que fossem levantados debates de cunho social e político sobre o cotidiano da comunidade a partir dos desafios realizados, muitas se sentiam envergonhadas e a maioria permanecia calada. A intenção foi aliar a teoria dos estudos do CinEducar dentro do Partejar Potiguara com a prática da produção fílmica que estava sendo desenvolvida e, assim, estimular a aproximação dessas mulheres com o pensar sobre sua ancestralidade e a cultura do seu povo.

Em uma das rodas de conversa, uma das alunas disse que não sabia o $\frac{\text { significado dos acessórios e pinturas usados dentro da comunidade e foi }}{\text { LUCENA, Micaelle Lages; VALLE, Isabella Chianca Bessa Ribeiro do. CinEducar e Partejar Potiguara: }}$ o ensino do cinema para mulheres indígenas como ferramenta de (r)existência. Revista GEARTE, Porto Alegre, v. 7, n. 2, p. 372-400, maio/ago. 2020.

Disponível em: http://seer.ufrgs.br/gearte 


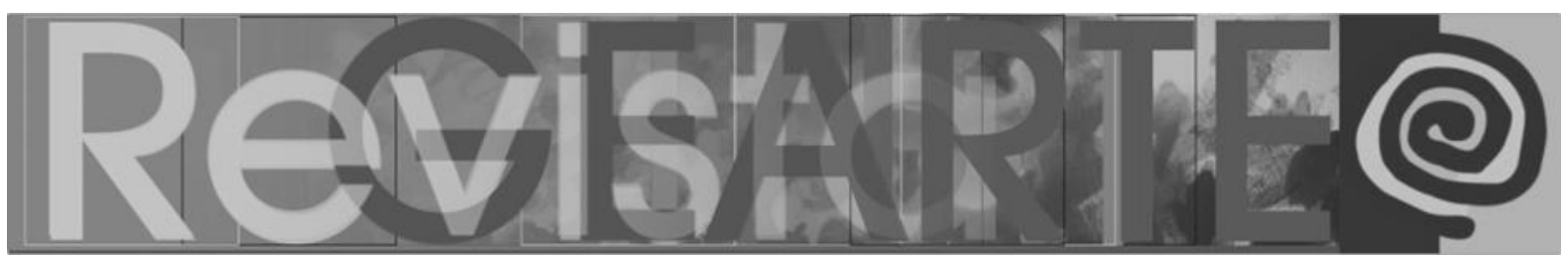

repreendida por sua tia. O proposto pelo projeto era justamente o inverso da repreensão: um ambiente de acolhimento sem medo, em que fosse possível debater e se ajudar umas às outras na construção desses conhecimentos.

O produto final do Partejar Potiguara foi um documentário em que a única aluna que frequentou a todas as aulas durante $o$ ano letivo inteiro do projeto em 2019 escolheu o tema a ser abordado, como o resultado de uma longa caminhada que aliou aprendizado da técnica com discussão social.

\begin{abstract}
A ajuda autêntica, não é demais insistir, é aquela em cuja prática os que nela se envolvem se ajudam mutuamente, crescendo juntos no esforço comum de conhecer a realidade que buscam transformar. Somente numa tal prática, em que os que ajudam e os que são ajudados se ajudam simultaneamente, é que 0 ato de ajudar não se distorce em dominação do que ajuda com sobre quem é ajudado. (FREIRE, 1978, p. 15).
\end{abstract}

Ela foi a autora do documentário final, produzido com auxílio de toda equipe universitária do projeto. Outras duas alunas apareciam esporadicamente nos dias marcados, mas a realizadora do filme foi a única que sempre estava presente e inclusive costumava enviar mensagens dizendo que seguiria até o fim. Foi conversado com ela sobre qual tema ela gostaria de tratar no documentário e, depois das conversas incitadas pelo projeto Partejar Potiguara e os filmes exibidos na comunidade por outra vertente do projeto, ela propôs um filme sobre a história de sua mãe, que teve 11 filhos partejados por parteiras tradicionais indígenas.

As últimas aulas foram de realização do documentário, de diálogo com sua mãe para que ela partilhasse, de frente com a própria filha, para além dos partos, histórias sobre sua vida e as relações que provêm desse tema: as suas histórias com sua própria mãe e o que aprendeu na vida da maternidade. Depois do filme pronto, a aluna se mostrou interessada em participar de festivais de cinema e espalhar o filme para que seja assistido por mais pessoas.

Começando pelo meio e sendo levado por caminhos inesperados até um resultado final que não é possível prever, o Partejar Potiguara cumpre o esperado do projeto: fortalecer o ensino do cinema como potência de luta e resistência. 


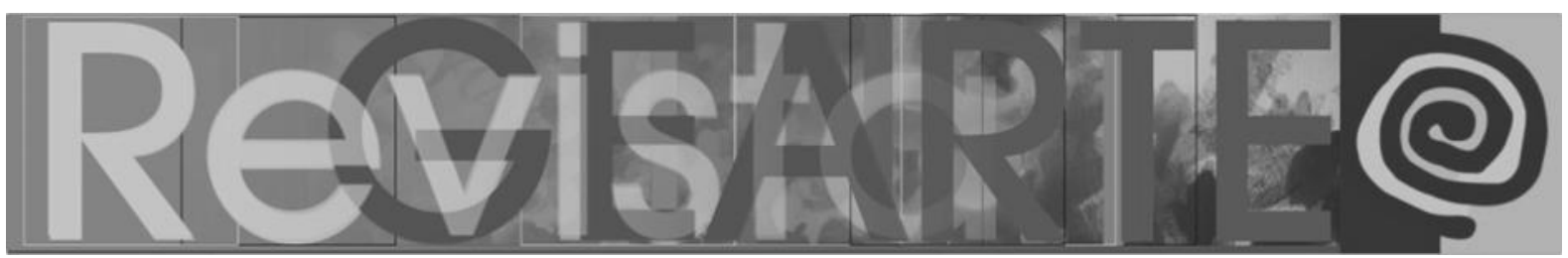

Através dele adolescentes reestabeleceram conexões com as raízes de seu povo, valorizando a própria identidade, e uma mulher indígena tornou-se autora da sua própria história, narrada em um filme, contada de dentro de seu lar, sobre sua ancestralidade e cultura e com a oportunidade de levar esse olhar sobre sua realidade para vários espectadores.

\title{
Considerações finais
}

\begin{abstract}
Se examinarmos criticamente o papel tradicional da universidade na busca da verdade e na partilha de conhecimento e informação, ficará claro, infelizmente, que as parcialidades que sustentam e mantêm a supremacia branca, o imperialismo, o sexismo e o racismo distorceram a educação a tal ponto que ela deixou de ser uma prática da liberdade. (hooks, 2013, p. 45).
\end{abstract}

$\mathrm{Na}$ grade curricular tradicional dos cursos de bacharelado não se propõe ensinar metodologias de partilha dos conhecimentos a fim de estender as fronteiras dos muros da universidade para os espaços populares. São necessários os outros dois pilares fundamentais da universidade: a pesquisa e a extensão, que incentivam os aprofundamentos dos saberes e a aplicação em campo. A tríade (ensino, pesquisa e extensão) fortalece o aprendizado e expande as possibilidades do saber. As experiências do Partejar Potiguara, através das reflexões do CinEducar, mostram que é partilhando conhecimentos, ocupando espaços e fortalecendo cooperações para que todas as pessoas tenham suas vozes ouvidas o único caminho para tal prática da liberdade. A educação não hierarquizada, que exerce a prática de ouvir coletivo para não silenciar, é o que descontrói conceitos de competição, autoridade e poder. Na sala de aula deve existir espaço para todas as pessoas.

Ensinar arte é incentivar a subjetividade, o questionamento e a criticidade. A arte carrega a individualidade do artista que produz e também suas pautas pessoais, sociais e políticas. É discurso imagético. É um constante processo de reflexão e externalização, produção de saberes e de memórias. É um processo de ocupar espaços e fazer sua voz ser ouvida, militando por questões individuais e de 


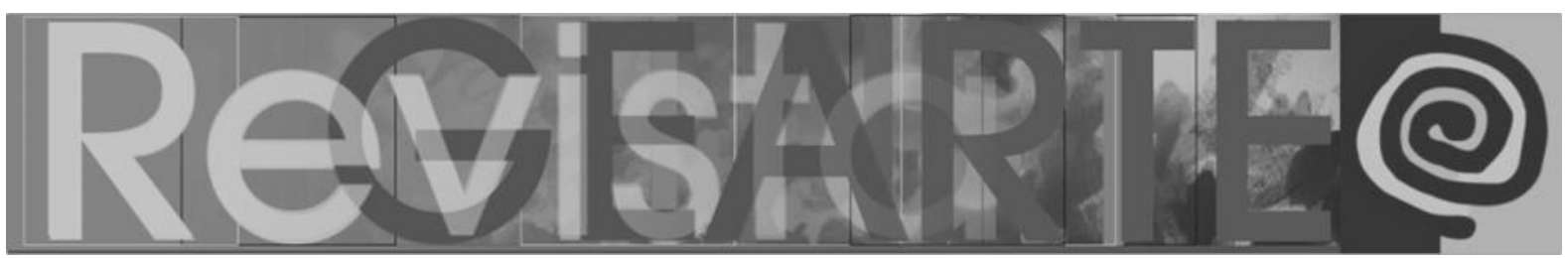

seu grupo e enfrentando as perseguições silenciadoras. É, enfim, resistência. Por isso a expressão artística anda, e deve sempre andar, de mãos dadas com as minorias, contra a padronização, assimilação e aniquilação pretendidas pelo projeto capitalista colonizador.

Refletir sobre a educação libertadora, proposta e discutida por Freire, é o mínimo na tentativa de produzir uma reparação histórica para os grupos que sofreram exploração, dominação e extermínio por séculos. É construir um sistema de ensino da arte voltado para a realidade social, que reconhece o valor na particularidade e nas experiências de cada sujeito e grupo e no que eles podem contribuir, levando em conta o contexto em que estão inseridos e desmistificando a ideia de que apenas a ciência eurocentrada é forma legítima de saber.

Incentivar o acesso e a instrumentalização de populações, os mais diversos possíveis, dentro de espaços de expressão privilegiados, como o cinema, é tentar quebrar o sistema vigente excludente e marginalizante. É dar visibilidade à diversidade de olhares e de histórias a serem contadas. Adotar esse método de ensino aliado a essas reflexões demanda uma tentativa incessante de encontrar os caminhos, com todo cuidado possível e criatividade, mas sem medo de errar, com solidariedade, para se permitir ser flexível e mergulhar nas experiências do ensino enquanto aprendizagem, encontrando prazer no constante trabalho de trocar conhecimentos.

\section{Referências}

AUMONT, Jacques. Olho interminável: cinema e pintura. São Paulo: Cosac \& Naify, 2004.

BARBOSA, Andréa. Antropologia e imagem. Rio de Janeiro: Zahar, 2006.

CABRAL, Cléber; BORGES, Diogo. Rizoma: uma introdução aos Mil Platôs de Deleuze e Guattari. Revista Critério [on-line], v. 1, n. 4, 2005.

COSTA, Adriane Camilo; MARTINS, Alice Fátima. O cinema como mediador na educação da cultura visual. Visualidades, v. 6, n. 1 e 2, 2012.

DE BARROS, Laura Pozzana; KASTRUP, Virgínia. Cartografar é acompanhar processos. In: PASSOS, Eduardo; KASTRUP, Virgínia; DA ESCÓSSIA, Liliana. (Orgs.). Pistas do método da cartografia: pesquisa-intervenção e produção de subjetividade. Porto Alegre: Sulina, 2009. 


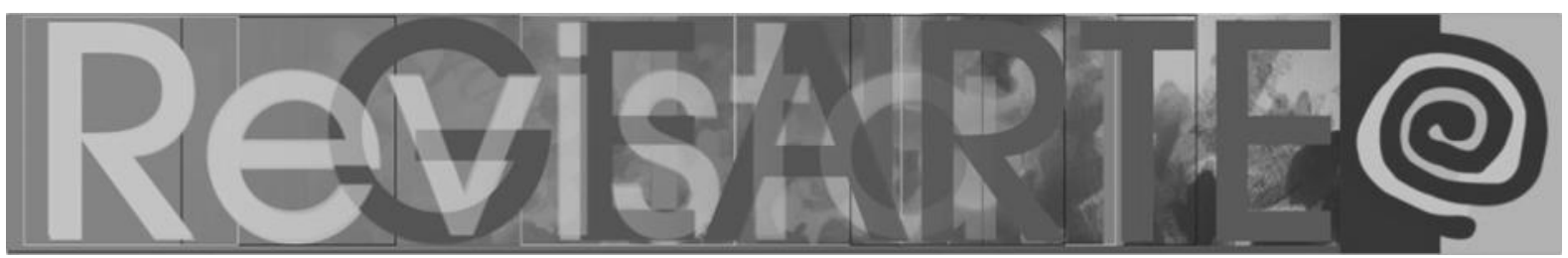

FOUCAULT, Michel. Vigiar e punir: história da violência nas prisões. Tradução de Raquel Ramalhete. Petrópolis/RJ: Vozes, 2000.

FREIRE, Paulo. Pedagogia da autonomia: saberes necessários à prática educativa. Rio de Janeiro: Terra e Paz, 1996.

FREIRE, Paulo. Cartas à Guiné-Bissau: registros de uma experiência em processo. 3. ed. Rio de Janeiro: Paz e Terra, 1978.

hooks, bell. Ensinando a transgredir: a educação como prática da liberdade. São Paulo: WMF Martins Fontes, 2013.

MIGLIORIN, Cezar. Cinema e escola, sob o risco da democracia. In: FRESQUET, Adriana. Dossiê cinema e educação \#1: uma relação sob a hipótese de alteridade de Alain Bergala. Rio de Janeiro: Booklink; CINEAD-LISE-FE/UFRJ, 2011. p. 130-136.

MOGADOURO, Cláudia. A perspectiva indígena no cinema. Grupo Cinema Paradiso, 2016. Disponível em: http://www.grupocinemaparadiso.com.br/2016/04/a-perspectiva-indigena-nocinema.html. Acesso em: 19 jan. 2020.

MORIN, Edgar. O problema epistemológico da complexidade. 3. ed. Mira-Sintra/Portugal: Publicações Europa América, 2002.

NUNES, Karliane Macedo; DA SILVA, Renato Izidoro; SILVA, José de Oliveira dos Santos. Cinema indígena: de objeto a sujeito da produção cinematográfica no Brasil. Polis [on-line], n. 38, 2014. Disponível em: http://journals.openedition.org/polis/10086. Acesso em: 18 jan. 2020.

PASSOS, Eduardo; KASTRUP, Virgínia; DA ESCÓSSIA, Liliana. (Orgs.). Pistas do método da cartografia: pesquisa-intervenção e produção de subjetividade. Porto Alegre: Sulina, 2009.

PEREIRA, Eliana Alves et al. A contribuição de John Dewey para a Educação. Revista Eletrônica de Educação. São Carlos, São Paulo: UFSCar, v. 3, n. 1, p. 154-161, 2009.

RIBEIRO, Djamila. O que é lugar de fala? Belo Horizonte: Letramento: Justificando, 2017.

SLEUTJES, Maria Helena Silva Costa. Refletindo sobre os três pilares de sustentação das universidades: ensino-pesquisa-extensão. Revista de Administração Pública, v. 33, n. 3, p. 99-101, 1999.

TARKOVSKI, Andrei. Esculpir o tempo. 2. ed. São Paulo: Martins Fontes, 1998.

ZANETTI, Daniela. Cenas da periferia: autorrepresentação como luta por reconhecimento. ECompós, v.11, n.2, 26 jan. 2009. Disponível em: https://e-compos.emnuvens.com.br/ecompos/article/view/218. Acesso em: 18 jan. 2020.

\section{Micaelle Lages Lucena}

Graduanda em Cinema e Audiovisual pelo Departamento de Comunicação da Universidade Federal da Paraíba. Pesquisadora integrante do projeto de extensão Partejar Potiguara e do TATOlaboratório de pesquisa em imagens, corpos e afetações.

Orcid: https://orcid.org/0000-0003-1023-1657

E-mail: lagesmica@gmail.com

Currículo: http://lattes.cnpq.br/5611724951133376 


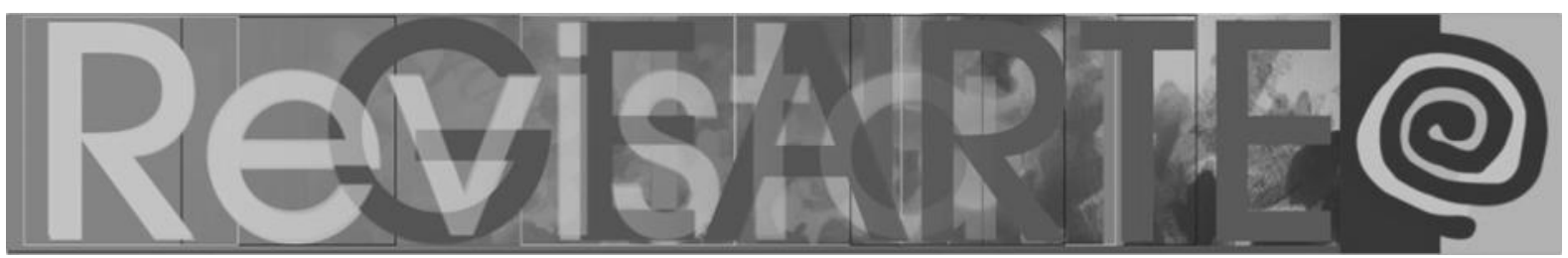

\section{Isabella Chianca Bessa Ribeiro do Valle}

Fotógrafa, pesquisadora e professora doutora no Programa de Pós-Graduação em Comunicação e do Departamento de Comunicação da Universidade Federal da Paraíba. Mestre em Comunicação e Semiótica pela Pontifícia Universidade Católica de São Paulo, com dissertação sobre fotografia e tecnologias digitais, desenvolveu sua tese de doutorado no Programa de Pós-Graduação em Comunicação da Universidade Federal de Pernambuco (UFPE) a respeito das mulheres fotógrafas do Recife. É bacharel em Comunicação Social/Jornalismo pela mesma UFPE, estudou Comunicación Audiovisual na Universidad de Sevilla (Espanha) e é colaboradora do Laboratoire Arts des Images et Art Contemporain na Université Paris 8 (França), onde foi pesquisadora convidada. Atualmente integra o coletivo 7Fotografia, de mulheres fotógrafas; cocoordena o projeto de extensão Partejar Potiguara, com mulheres indígenas e coordena o TATO - laboratório de pesquisa em imagens, corpos e afetações.

Orcid: https://orcid.org/0000-0001-6994-258X

E-mail: bella.valle.ufpb@gmail.com

Currículo: http://lattes.cnpq.br/2859317457070176

Recebido em 31 de janeiro de 2020 Aceito em 17 de maio de 2020 